\title{
Landscape-Scale Forest Reorganization Following Insect Invasion and Harvest Under Future Climate Change Scenarios
}

\author{
Stacey K. Olson, ${ }^{1}$ Erica A. H. Smithwick, ${ }^{1,4 *} \odot$ Melissa S. Lucash, ${ }^{2}$ \\ Robert M. Scheller, ${ }^{3}$ Robert E. Nicholas, ${ }^{4}$ Kelsey L. Ruckert, ${ }^{5}$ and \\ Christopher M. Caldwell ${ }^{6}$
}

\begin{abstract}
${ }^{1}$ Department of Geography, The Pennsylvania State University, 302 Walker Building, University Park, Pennsylvania 16802, USA; ${ }^{2}$ Department of Geography, University of Oregon, Eugene, Oregon 97403-1251, USA; ${ }^{3}$ Department of Forestry and Environmental Resources, North Carolina State University, Campus Box 8008, Raleigh, North Carolina 27695-8008, USA; ${ }^{4}$ Earth and Environmental Systems Institute, The Pennsylvania State University, 2217 Earth-Engineering Sciences Building, University Park, Pennsylvania 16802-6813, USA; ${ }^{5}$ RPS, 55 Village Square Drive, South Kingstown, Rhode Island 02879, USA; ${ }^{6}$ College of Menominee Nation, Sustainable Development Institute, N172 Wisconsin State Highway 47/55, Keshena, Wisconsin 54135, USA
\end{abstract}

\begin{abstract}
Emerald ash borer (EAB; Agrilus planipennis Fari-
\end{abstract}

Received 29 April 2020; accepted 31 January 2021; published online 17 March 2021

Supplementary Information: The online version contains supplementary material available at https://doi.org/10.1007/s10021-021-0061 6-W.

Authors Contributions: SKO contributed to the research design, carried out the entirety of data generation (LANDIS-II simulations) and analysis, and authored the entirety of this work, with editing assistance from co-author Smithwick. EAHS contributed to the research design, including genesis of the overarching theme and study area, as well as suggestions for data analysis. Smithwick also offered suggestions and feedback throughout the research process and provided editorial support to multiple versions of the manuscript. MSL contributed to the research design, gathered input data and maps, and calibrated the model for the study area. Lucash also provided suggestions for data analysis, and technical support throughout the data generation process. RMS contributed to the research design and provided guidance and technical support throughout the data generation process. REN contributed to the research design through furnishing information and data pertaining to climate change scenarios, and provided technical support and guidance for using high-performance computing infrastructure. KLR provided technical support and guidance in using high-performance computing infrastructure with specific expertise in carrying out LANDIS-II simulations on a Linux system. CMC provided support for collaborating with the Menominee Indian Tribe of Wisconsin and informed the writing process through an indigenous lens.

*Corresponding author; e-mail: Smithwick@psu.edu maire) has been found in 35 US states and five Canadian provinces. This invasive beetle is causing widespread mortality to ash trees (Fraxinus spp.), which are an important timber product and ornamental tree, as well as a cultural resource for some Tribes. The damage will likely continue despite efforts to impede its spread. Further, widespread and rapid ash mortality as a result of EAB is expected to alter forest composition and structure, especially when coupled with the regional effects of climate change in post-ash forests. Thus, we forecasted the long-term effects of EAB-induced ash mortality and preemptive ash harvest (a forest management mitigation strategy) on forested land across a 2million-hectare region in northern Wisconsin. We used a spatially explicit and spatially interactive forest simulation model, LANDIS-II, to estimate future species dominance and biodiversity assuming continued widespread ash mortality. We ran forest disturbance and succession simulations under historic climate conditions and three downscaled CMIP5 climate change projections representing the upper bound of expected changes in precipitation and temperature. Our results suggest that although ash loss from $\mathrm{EAB}$ or harvest 
resulted in altered biodiversity patterns in some stands, climate change will be the major driver of changes in biodiversity by the end of century, causing increases in the dominance of southern species and homogenization of species composition across the landscape.

Key words: Emerald ash borer; LANDIS-II; Forest simulation model; Northwoods; Biodiversity.

\section{HighLights}

- By 2100, changes in climate overwhelm the impact of EAB-related disturbance.

- Overall biodiversity declines under climate change.

- Ash loss has important relevance at the site level but little landscape-level impact.

\section{INTRODUCTION}

Emerald ash borer (EAB; Agrilus planipennis Farimaire; Coleoptera: Bruprestidae) is an invasive phloem-boring beetle that was first introduced to the USA from Southeast Asia in the 1990s (Cappaert and others 2005; Siegert and others 2014). It has been described as one of the most destructive invasive exotic species in North America (Krist and others 2014). To date, the presence of EAB has been confirmed in 35 states and five Canadian provinces. County-level quarantines are implemented wherever EAB presence is confirmed as a means of preventing its spread (Herms and McCullough 2014). However, EAB continues to spread rapidly due to the difficulty associated with identifying an infested tree before adult emergence and host tree mortality occur (Herms and McCullough 2014). Additionally, long-distance spread, which introduces new pockets of infestation, has been facilitated through human-assisted migration via packing materials or firewood (BenDor and others 2006; Muirhead and others 2006). Native North American ash trees (Fraxinus spp.), specifically black ash ( $F$. nigra Marsh.), green ash ( $F$. pennsylvanica Marsh.), and white ash (F. americana L.) are most preferred (Agius and others 2005; Cappaert and others 2005; Anulewicz and others 2007; Herms and McCullough 2014), exhibit little to no resistance to the beetle, and continue to die off in large numbers since EAB's initial detection in the USA (Knight and others 2013; Herms and McCullough 2014; Siegert and others 2014).

The spread of EAB has resulted in extensive economic and cultural damage throughout much of the Northeastern and Midwestern USA (Herms and McCullough 2014; Costanza and others 2017). Early projections of the economic cost of failure to contain EAB estimated the value of ash sawtimber stock in the Eastern USA to be $\$ 25$ billion, with an additional $\$ 20$ to $\$ 60$ billion possible through damage to urban forests across the country (U.S.D.A. 2003). Since its discovery, economic damages incurred from the quarantines, removal of infested and dead trees, and lost timber and nursery stock have resulted in EAB becoming the costliest non-native insect to invade US forests (Herms and McCullough 2014). Research on EAB has focused on quantifying spread rate based on empirical data from the field (Mercader and others 2009; Siegert and others 2014) and using geospatial simulation modeling to project future spread (BenDor and others 2006; Muirhead and others 2006; Prasad and others 2010; Anderson and Dragicevic 2016). Such forecasts can be used as decision support tools for forest managers and municipal planners interested in reducing the economic impact of $\mathrm{EAB}$ through slowing or impeding its spread (Poland and Mccullough 2010; Bossenbroek and others 2015), for example by identifying the role of preemptive ash harvest to mitigate spread and manage forest change. Ash harvest before and immediately following $\mathrm{EAB}$ invasion can mitigate the negative economic consequences of EAB spread by providing a usable wood resource from which communities and land managers can profit, rather than losing the resource altogether (Mercader and others 2011; Rabaglia and Chaloux 2011). Further, ash reduction through targeted harvest might be a viable management option for reducing the spread of $\mathrm{EAB}$, especially when combined with other management strategies, including systemic insecticide application and girdling and destroying sacrificial trees, or "trap cropping" (Mercader and others 2011). Although potentially useful in slowing the spread of EAB and mitigating the economic damages of lost timber stock, ash removal might result in several negative ecological impacts. Thus, management plans should be in place well before $E A B$ is discovered in an area, especially in places where there is a significant ash component and/or areas where there are ecologically sensitive ash resources (Rabaglia and Chaloux 2011). Similarly, information about EAB spread, coupled with effective prevention, response, and recovery plans, can be used by groups interested in preserving black ash as 
a cultural keystone species (Costanza and others 2017).

Ash mortality due to EAB, which occurs within a few years, can be expected to create widespread, synchronous gaps in forest ecosystems where the cascading effects of successional dynamics might alter community composition and ecosystem processes (Herms and McCullough 2014). Loss of ash may facilitate a shift in native tree composition, as evidenced by other similar events, such as an increase in oaks following the chestnut blight outbreak in Eastern US forests (Wang and Hu 2015). In regions where ash is currently present, Acer and Ulmus species have the greatest potential to become dominant in forests following ash decline (Flower and others 2013). Ash loss might also facilitate the establishment and spread of invasive plant species and reduce food resources for native fauna that specialize on ash trees (Gandhi and Herms 2010). Furthermore, loss of ash trees over an extensive area will likely alter carbon fluxes through a reduction in net primary productivity (Flower and others 2013). Riparian areas where black ash dominates have received attention due to the fact that rapid loss of black ash results in substantial alteration of biogeochemical cycles, microclimates, and hydrologic regimes (Nisbet and others 2015; D'Amato and others 2018; Kolka and others 2018).

$\mathrm{EAB}$ is a wood-boring agent that is both hostspecific and highly virulent, but ash trees, based on proportional biomass alone, are not often of high importance in eastern forests and they tend to grow in mixed stands. Thus, while EAB is destructive, its impacts may be masked by its hosts' lack of pervasiveness at the regional scale (Lovett and others 2006). However, climate change might interact with the suitable habitat ranges and physiologies of both EAB and ash, which may alter the agent-host interactions we have come to understand (Lovett and others 2006; Liang and Fei 2014). It has been widely acknowledged that climate change is altering ecosystems and the services provided by such ecosystems are facing unprecedented degradation (USGCRP 2018). In addition, forest disturbances are known to be sensitive to climate, yet the effects of a changing climate on disturbance are not fully understood (Seidl and others 2017). Further, society-disturbance interactions and spatial variation in disturbance and successional processes often go unaccounted for in ecological research (Turner 2010). In northern Wisconsin, expected changes in climate are likely to alter forest composition, with a reduction in biomass of cool-adapted species, and an increase in warm-adapted species (Janowiak and others 2014). Moreover, changes are attributed to the relatively young age of forests in the area and the fact that their continued growth is, at the moment, outpacing removal due to harvest, natural disturbances, and senescence (Janowiak and others 2014). Notably, based on climate change projections alone, black ash biomass and white ash biomass are expected to increase over the century (Janowiak and others 2014). However, EAB invasion, like most non-native insect species invasions, has not been included previously in forecasts of forest composition in response to regional climate change, yet it is likely that the impacts of EAB on ash trees will overshadow the impacts of climate change over the next few decades (Janowiak and others 2014).

Despite the importance of potentially divergent successional trajectories and the impacts of $E A B$ on biodiversity and ecosystem processes, landscapelevel impacts are unknown (Klooster and others 2018). Moreover, the potential ecological impacts of EAB-induced ash mortality have mostly been predicated on an assumption that the long-term persistence of ash trees in eastern forests is unlikely (Klooster and others 2014; Smith and others 2015; Morin and others 2017), but have not examined the interactive effects of ash loss, forest harvest strategies, and changing climate. This research examines forest reorganization at the landscape scale, here defined as the study area extent covering over 2 million ha, following EAB invasion in a climatically uncertain future. Importantly, climate change is likely to influence the magnitude and direction of vegetation reshuffling, so it is important to incorporate climate change projections into the understanding of how EAB dynamics shape forest change.

Our overarching research question was: How might landscape-level forest composition and biomass change through time as a result of the combined impacts of ash loss and climate change? Based on results of Janowiak and others (2014), we hypothesized that at the landscape scale, southernand warm-adapted tree species will increase in biomass by the end of century, but that overall biodiversity will decline due to the loss of northernadapted species. For a given forest stand, we hypothesized that species richness will be lower in areas of EAB disturbance due to the loss of ash species, but that overall biomass will remain unchanged due to rapid infill by other trees in areas of ash mortality. 


\section{Materials ANd Methods}

\section{Site Description}

The study area encompassed just over 2 million ha in northeastern Wisconsin, USA (Figure 1). This area is well suited for studying the impacts of insect disturbance and climate change for several reasons, including the prevalence of EAB in the area and the fact that this area of Wisconsin lies in a "ten- sion zone," defined by steep climatic gradients and ecotone boundaries (Curtis 1959; Anderson 2005; Kucharik and others 2013). In Wisconsin, EAB has been detected in eleven counties that are included in our landscape, including Florence, Oneida, Marinette, Marathon, Portage, Waushara, Waupaca, Winnebago, Outagamie, Brown, and Oconto (Wisconsin Department of Agriculture and Trade and Consumer Protection 2020; WIDNR 2018).

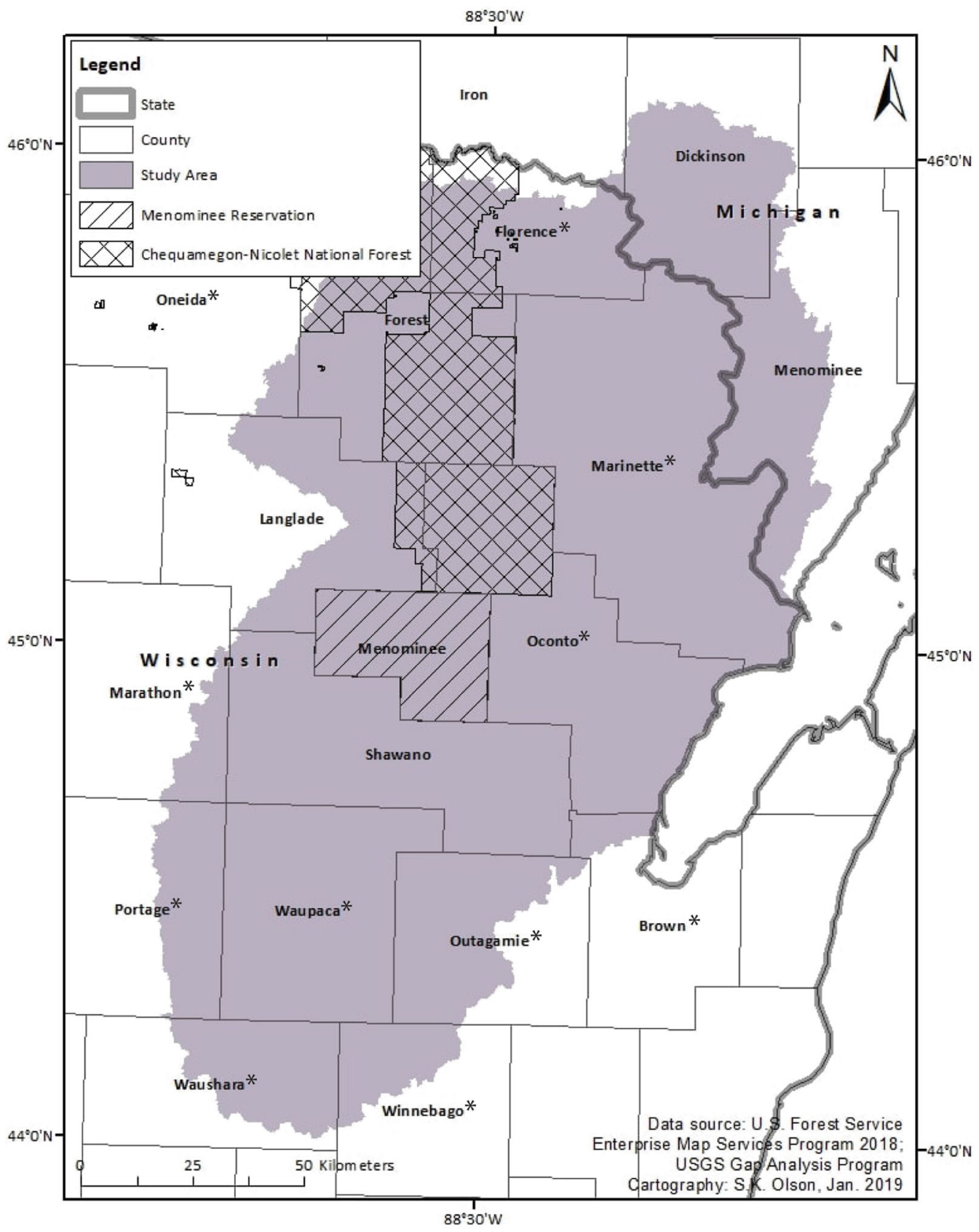

Figure 1. Study region for this research with implicated federal, state, and county jurisdictions labeled. Of the Wisconsin counties labeled on this map, eleven have confirmed EAB detections, including Florence, Oneida, Marinette, Marathon, Portage, Waushara, Waupaca, Winnebago, Outagamie, Brown, and Oconto counties. 
Thus, EAB poses an imminent threat to the study area and forest managers there are concerned about the potential cultural, ecological, and economic impacts of ash loss, such as those outlined in the introduction. This is especially true within the Menominee Reservation, where tribal forest managers have been actively managing for sustainable timber harvest and multi-benefit forest use for over 150 years (Dockry and others 2016).

This region is underlain by three primary soil types: forested, loamy soils; forested, red, sandy, and loamy soils; and forested, sandy soils (Wisconsin Department of Natural Resources 2015). Minor soil types in the region include stream-bottom and major wetland soils and forested, red, clayey, or loamy soils (Wisconsin Department of Natural Resources 2015). Wisconsin is characterized by a continental climate with some modification from Lake Michigan to the east and Lake Superior to the north. The study region falls mostly within the northeast climate division, where average seasonal temperatures range from $18.2{ }^{\circ} \mathrm{C}$ in the summer (June, July, and August) to $-8.8^{\circ} \mathrm{C}$ in the winter (December, January, and February) (Wisconsin State Climatology Office 2016). Nonsnow precipitation is greatest in the summer, averaging $28.4 \mathrm{~cm}$, and lowest in the winter, averaging $9.6 \mathrm{~cm}$, and annual average snowfall is $151.1 \mathrm{~cm}$ (Wisconsin State Climatology Office 2016). In northern Wisconsin, the annual average temperature increased by $0.8^{\circ} \mathrm{C}$ between 1901 and 2011 and mean annual precipitation increased by $6.5 \%$ in the same time period (Janowiak and others 2014).

Wisconsin forests share similar histories with other midwestern states. Prior to Euro-American settlement, forest vegetation was largely determined by interactions between climate, soils, topography, and natural disturbances, including fire, tree falls, and wind, as well as intentional burning by indigenous populations (Kassulke and Mladenoff 2010). The federal government's allotment of tribal lands to settlers and timber companies in the mid-1800s led to drastic changes in vegetation throughout the state that lasted through the early 1900s (Rhemtulla and others 2009; Kassulke and Mladenoff 2010). In the north, the combined effect was a large decline in evergreen conifers, namely pines and hemlocks, while in the south, wetlands that supported lowland species were lost to drainage and development (Rhemtulla and others 2009; Kassulke and Mladenoff 2010). Agricultural abandonment and sustainable timber harvesting practices have contributed to reforestation in the state since the mid-1960s, with early successional species coming to dominate in areas of prior cultivation (Kurtz and others 2017).

In tension zones, even small changes in climate can dramatically shift species composition, creating novel communities over time. Presently, forest composition in the study area changes along a latitudinal gradient defined by the tension zone, with the northern and central areas being comprised of West Laurentian mixed conifer-broadleaf forest and the southerly extent being comprised of Midwest broadleaf forest (Perry and others 2004). The study area is primarily dominated by Maple/ Beech/Birch and Aspen/Birch forests, which is consistent with forest dominance in the state as a whole (Perry and others 2004). Black ash, green ash, and white ash are widely dispersed in the study area and are usually an associate species in several forest types, though black ash can be a dominant species in swampy woodlands, bogs, and along streams (Burns and Honkala 1990). Green ash is highly adaptable and can grow well in areas subject to flooding, moist but well-drained upland sites, alluvial soils, and swamps (Burns and Honkala 1990). White ash grows best on moderately well-drained soils, though it is somewhat tolerant of temporary flooding (Burns and Honkala 1990).

\section{Modeling Framework}

To study the ecological consequences of EAB, harvest, and climate change over a large region through year 2100, we used the forest landscape simulation model LANDIS-II (v6.0), which is both spatially explicit and spatially interactive (Mladenoff 2004; Scheller and others 2007). LANDIS-II is raster-based; landscapes are represented as a grid of cells through which disturbance and succession dynamics, such fire and seed dispersal, can interact over space and time. Individual cells are populated with tree and shrub species, which are binned into species-age cohorts, as well as information about soil characteristics and live and dead biomass. Each tree and shrub species has a unique set of life-history attributes, which determine how the species grows, reproduces, and dies, and how it interacts with disturbances and climate. LANDIS-II is modular, allowing the user to specify which disturbances to simulate and which successional dynamics to track. For this study, we used a succession module that incorporates climate change projections and we simulated EAB-related disturbance in two ways to represent natural EAB-induced ash mortality, as well as preemptive removal of susceptible ash trees, a harvesting strategy aimed to promote sustainable forestry in the face of EAB. 
Each of these components is described below. (For a complete description of LANDIS-II modules used in this study, please refer to "Appendix A".) A spatial resolution of 1 ha was used in all simulations.

Succession was simulated using the Net Ecosystem Carbon and Nitrogen (NECN) module (v5.0) for LANDIS-II (Scheller and others 2011). NECN calculates and tracks how species-age cohorts grow, reproduce, age, and die (Scheller and others 2011). It also tracks live and dead biomass through time, as well as a suite of other biogeochemical processes (Scheller and others 2018). NECN incorporates elements of the CENTURY soils model (Scheller and others 2011), with new N cycling algorithms (Lucash and others 2014). NECN accepts daily or monthly climate inputs, which can be represented heterogeneously across the landscape by defining areas where region-specific climate streams are similar (Lucash and Scheller 2019).

We simulated 37 distinct tree species representing seven user-defined functional groups (Table 1) that share similar traits (Lucash and others 2019). These traits include: temperature effect on growth, how much aboveground net primary productivity (ANPP) is allocated to leaves, how leaf area index (LAI) is calculated, sensitivity to low water availability, woody decay rate, monthly wood mortality, age-related mortality, leaf drop month, and the fraction of ANPP that is used to compute the ANPP of coarse and fine roots (Scheller and others 2018). Succession is determined by mechanistic assumptions related to tree physiology and how initial conditions within the simulated cell (i.e., which species are dominant in the canopy and understory) interact with climate. However, stochastic processes, such as disturbance, seed dispersal, and probability of establishment, can alter successional pathways. Probability of establishment is determined by growing degree days, drought tolerance, minimum January temperature, and LAI (a proxy for light availability) (Scheller and others 2018). Cohort growth is determined by LAI, water availability, temperature, growing space capacity, and $\mathrm{N}$ availability (Scheller and others 2018). Details about the parameterization and calibration of NECN in our landscape can be found in (Lucash and others 2019).

\section{Emerald Ash Borer Simulation}

For the purpose of this study, we assumed there will be widespread ash mortality in the study region within a few decades. Empirical work quantifying EAB spread rate based on dendrochronology and modeling studies corroborate this assumption (Siegert and others 2014; Gustafson and others 2017). Further, research into the effects of community composition and structure on EAB-induced mortality suggests that native North American ash species might soon become functionally extinct (Smith and others 2015). We used the Biological Disturbance Agent (BDA) module (v3.0) for LANDIS-II (Sturtevant and others 2004) to simulate ash mortality on the landscape. BDA uses host tree age information, insect dispersal patterns, and cell and neighborhood level characteristics to determine the probability of disturbance and mortality at a given site during every time step in the simulation (Sturtevant and others 2017). If a cell is vulnerable to disturbance, the module will determine the probability of mortality for the species-age cohorts present in the cell and remove candidate cohorts if necessary, thereby killing susceptible trees.

The impending invasion by EAB has led forest managers in the region to implement management plans intended to dampen the negative economic, ecological, and cultural effects of ash mortality (USFS 2012; Menominee Tribal Enterprises 2018). For example, one plan involves removal of infested ash trees in old growth stands to slow or arrest further spread of EAB (USFS 2012). Another involves preemptive harvest of white ash trees larger than 5 in diameter at breast height (DBH) and experimental sanitation harvests, or complete removal, of black and green ash in some stands (Menominee Tribal Enterprises 2018). To examine the potential outcomes of such a management practice, we used the Base Harvest (v3.1) module (Gustafson and others 2000) to simulate a simplified version of the two harvest prescriptions: one for white ash removal and one for black and green ash removal. Base Harvest uses age information of targeted species at the cell level and user-defined harvest area targets to simulate human removal of trees in designated management zones. The Menominee Reservation was designated as one management zone and was subdivided into equal area stands measuring about 15 ha each, which is sufficiently small enough to mimic real-world harvesting practices without creating a computational burden. In this area, sustainable timber harvest practices dictate that thinning and individual tree selection occurs in all stands every 10 15 years (Menominee Tribal Enterprises 2012). Thus, we parametrized the module to "visit" every stand in the management zone within 15 years; every "visit" to a cell constitutes a harvest event if criteria ash trees are present in the cell. (For a 
Table 1. Species Modeled in LANDIS-II Simulations Organized by User-Assigned Functional Groups

\begin{tabular}{|c|c|}
\hline Functional group & Species included-common name (scientific Name) \\
\hline Aspens & $\begin{array}{l}\text { Bigtooth aspen (Populus grandidentata Michx.) } \\
\text { Quaking aspen (Populus tremuloides Michx.) } \\
\text { Willows }\end{array}$ \\
\hline Oaks (Quercus spp.) & $\begin{array}{l}\text { Bur oak } \\
\text { Pin oak } \\
\text { Red oak } \\
\text { White oaks }\end{array}$ \\
\hline Northern Hardwoods & $\begin{array}{l}\text { American beech (Fagus grandifolia Ehrh.) } \\
\text { Basswood (Tilia americana L.) } \\
\text { Black ash (Fraxinus nigra Marshall) } \\
\text { Green ash (Fraxinus pennsylvanica Marshall) } \\
\text { Hophornbeam (Ostrya Scop.) } \\
\text { Red maple (Acer rubrum L.) } \\
\text { Service berries (Amelanchier spp.) } \\
\text { Silver maple (Acer saccharinum L.) } \\
\text { Sugar maple (Acer saccharum L.) } \\
\text { White ash (Fraxinus americana L.) } \\
\text { Yellow birch (Betula alleghaniensis Britton) }\end{array}$ \\
\hline Southern Hardwoods & $\begin{array}{l}\text { Bitternut hickory (Carya cordiformis (Wangenh.) Koch) } \\
\text { Black cherry (Prunus serotina Ehrh.) } \\
\text { Black oak (Quercus velutina Lam.) } \\
\text { Butternut (Jugans cinerea L.) } \\
\text { Elms (Ulmus spp.) } \\
\text { Shagbark hickory (Carya ovata (Mill.) K. Koch) }\end{array}$ \\
\hline Northern Conifers & $\begin{array}{l}\text { Balsam fir (Abies balsamea L. (Mill.)) } \\
\text { Black spruce (Picea glauca (Moench) Voss) } \\
\text { Hemlock (Tsuga spp.) } \\
\text { Jack pine (Pinus banksiana Lam.) } \\
\text { Tamarack (Larix laricina (Du Roi) K. Koch) } \\
\text { White spruce (Picea mariana (Mill.) Britton, Sterns \& Poggenburg) }\end{array}$ \\
\hline Southern Conifers & $\begin{array}{l}\text { Red cedar (Juniperus virginiana L.) } \\
\text { Red pine (Pinus resinosa Ait.) } \\
\text { White cedar (Chamaecyparis thyoides (L.) Britton, Sterns, \& Poggenburg) } \\
\text { White pine (Pinus strobus L.) }\end{array}$ \\
\hline Birches & $\begin{array}{l}\text { Balsam poplar (Populus balsamifera L.) } \\
\text { Cottonwood (Populus L.) } \\
\text { Paper birch (Betula papyrifera Marshall) }\end{array}$ \\
\hline
\end{tabular}

complete description of model parameterization and information on input files, please refer to "Appendix B".)

\section{Climate Scenarios}

Climate change projection input files (daily resolution) were created using empirically downscaled CMIP5 (Taylor and other 2012) projections from the Multivariate Constructed Analogs (MACA) dataset (Abatzoglou and Brown 2012), which downscales CMIP5 outputs from their native spatial resolution of about $200 \mathrm{~km}$ to $4 \mathrm{~km}$. From the 40 projections in the MACA dataset, three climate change scenarios were selected representing moderate and high levels of warming as well as in- creased precipitation variability as averaged over the study region (see "Appendix C" and Figure S1 for details on the selected projections). For the historic climate scenario simulations, LANDIS-II randomized a 36-year (1979-2015) input of recorded historic climate data to generate a 100-year timeseries of temperature and precipitation. The study area was divided into 38 regions of relative climatic homogeneity using the methodology outlined in Lucash and others (2019). The spatial extent, configuration, and the number of climate regions capture the majority of spatial variability of the landscape's climate based on a geostatistical analysis of historical (1979-2010) weather data for the region (Figure S2) (Lucash and others 2019). 
The three future climate scenarios resulted in increases in mean annual temperature (MAT) over the next century (Figure S3). Between 2000 and 2100, MAT increased by $7{ }^{\circ} \mathrm{C}, 6.4{ }^{\circ} \mathrm{C}$, and $8.8^{\circ} \mathrm{C}$ under hot/dry, hot/wet, and hot/variable precipitation conditions, respectively. The scenarios chosen here are on the high side of mean projected changes (USGCRP 2017) but well within the range of projections from the bias-corrected multi-model ensemble (Figure S3). Projected changes in precipitation over the next century were more variable than projected changes in temperature. Total annual precipitation (TAP) averaged about $80 \mathrm{~cm}$ $($ range $=50-100 \mathrm{~cm})$ under historic climate conditions and, due to the model's randomization of precipitation data, shows no trend through time in our simulations, despite a slight trend toward increased precipitation in the historic record (Figure S4). Under hot/dry conditions, TAP increases slightly ( 80 to $85 \mathrm{~cm}$ by 2100 ; Figure S4), and slightly a greater amount (average $90 \mathrm{~cm}$ ) under the hot/wet projection. Under the hot/variable precipitation scenario, TAP does not show a strong trend through time but ranges from 30 to $150 \mathrm{~cm}$ (Figure S4). Averaged for the last 10 years of the time period (2090-2100), climate region (CR) 13, located in the northern part of the study area, was the coolest in temperature and CR 32, located in the southern part of the study area, was the warmest across historic and future climate scenarios (Table S1). CRs 13 and 32 were thus used in subsequent analyses to bound northern and southern variability in model response, respectively.

To account for stochasticity in the model from successional dynamics, seed dispersal and establishment, and EAB dynamics, four climate scenarios (historic, hot/dry, hot/wet, and hot/variable precipitation) were replicated five times each, for a total of 20 simulations.

\section{Statistical Analyses}

The response variables used to analyze changes in forest structure and composition through time were aboveground live biomass and species richness. Output maps of aboveground biomass for each species were generated at a yearly time step starting with the initial condition (Year 2000), resulting in 101 maps for each of the 37 species for each of the 20 simulations. Output maps of species richness, measured in number of species per cell, were generated for simulation years 0,50 , and 100 . In general, analyses were executed at the level of the climate "treatment" group; however, some analyses incorporated all 20 simulations. In most cases, analyses were carried out at the functional group level, though some species-level analyses were also performed to explain patterns within functional groups.

The number of scenario replicates $(n=5)$ was sufficiently high to capture variability arising from stochasticity within the model (Lucash and others 2017), but was insufficient for use in parametric statistics; thus, all analyses used nonparametric tests of significance. We used the Wilcoxon-MannWhitney test to determine differences between average end-of-century functional group biomass and average species richness in disturbed cells and undisturbed cells, as well as between cells where ash eradication occurred and cells where ash was not present under initial conditions. Undisturbed cells serve as a control against which we can analyze the effect of EAB-related disturbance on biomass and richness. We used the Wilcoxon-MannWhitney test to determine if disturbance and ash eradication affected end-of-century biomass (averaged across all cells in the study area). We used the Chi-square test to determine if disturbance and ash eradication affected whether a species became one of the most abundant species by the end of century. We also used the Wilcoxon-Mann-Whitney test to determine differences in average species richness between years 2050 and 2100 across climate scenarios and the Kruskal-Wallis test and post hoc Wilcoxon rank sum test to determine differences among scenarios. Similarly, these tests were used to determine differences in end-of-century average species richness among disturbed cells, undisturbed cells, cells that did not contain ash under the initial condition, and cells where ash was eradicated. All analyses of output data were carried out in $\mathrm{R}$ (v.3.5.1) (RStudio Team 2016; R Core Team 2018) using the raster package (v.2.8-19) (Hijmans 2019).

\section{RESUltS}

\section{Simulated Extent of Ash Decline}

Under initial conditions, ash is present in $48 \%$ of the cells on the landscape, but only present in $9.8 \%$ of cells by the end of century and its abundance is greatly reduced in those cells (Figure 2) as a result of extensive ash harvest or EAB invasion or both (Figure S5). Some cells that experienced ash harvest and/or EAB invasion or both were left with little to no ash biomass by the end of the century, although some maintained ash presence, likely due to regrowth. In either case, it is clear that these cells experienced one or both disturbances-ash harvest 


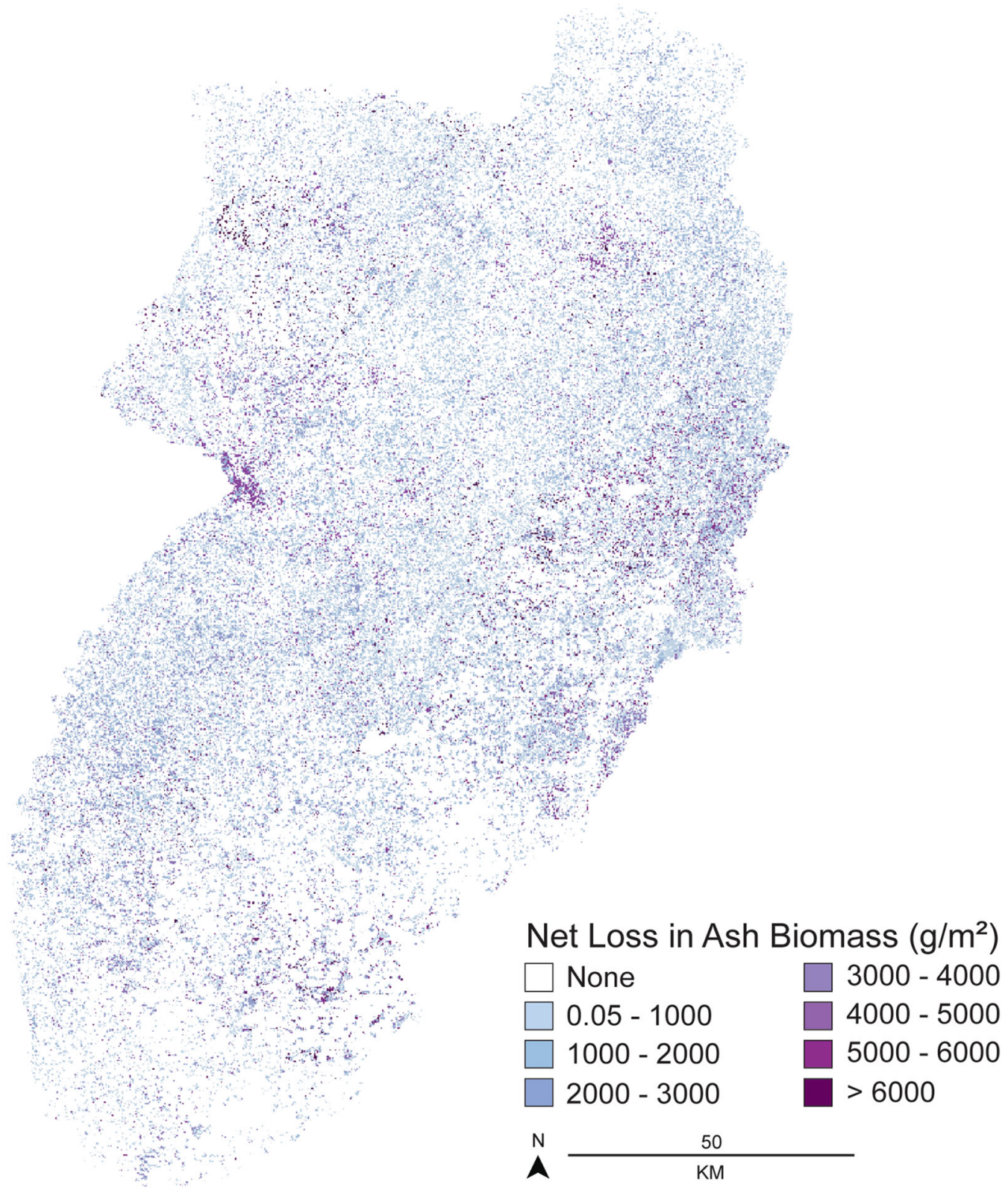

Figure 2. Net loss in ash biomass (absolute values, g/m²) between years 2000 and 2100 .

or EAB invasion-during the simulation, and are thus hereafter referred to as "disturbed" cells. We further distinguished between disturbed cells by isolating those cells that experienced a near complete loss of ash biomass ( $>99 \%$ ) by the end of the century; these sites are described here using "ash eradicated" or "ash eradication," though we acknowledge that these cells may be repopulated with ash in the future. Cells that did not experience any disturbance throughout the century are referred to as "undisturbed" cells. Averaged across all scenarios, roughly $68 \%$ of cells experienced dis- turbance by 2100 , while about $32 \%$ remained undisturbed. Of those cells that were disturbed, roughly $29 \%$ experienced ash eradication.

\section{Effects of Ash Loss on Relative Functional Group Biomass}

Functional group biomass differed by the end of century between disturbed and undisturbed cells, in both historical and climate change scenarios. Aspens and oaks had a significantly lower end-ofcentury average biomass in disturbed cells compared to undisturbed cells (Wilcoxon $W=690$, 
$p<<0.05$; Wilcoxon $W=1789, p<<0.05)$. Northern hardwoods, northern conifers, and southern conifers had significantly higher end-ofcentury average biomass in disturbed cells compared to undisturbed cells (Wilcoxon $W=30,436$, $p<<0.05$; Wilcoxon $W=9134, \quad p<<0.05$; Wilcoxon $W=4400, p<<0.05$ ). Southern hardwoods and birches did not show clear end-of-century biomass responses to disturbance status. Ash loss was not a predictor of average end-of-century biomass $(W=182, p=0.73$ ) or whether a species became one of the most abundant species by biomass in year $2100\left(\mathrm{X}^{2}=2.6 \mathrm{E}-31, p=1\right)$.

\section{Effects of Ash Loss on Species Richness}

Disturbance (preemptive harvest and EAB invasion) and ash eradication affected species richness, defined here as the number of species per cell. For both historical and climate change scenarios, endof-century mean species richness was highest in disturbed cells and lowest in undisturbed cells (Figure S6). Mean species richness differed based on disturbance and ash loss status (Kruskal-Wallis $\left.\mathrm{X}^{2}=49.79, \mathrm{df}=3, p<<0.05\right)$. There was no difference in mean species richness between disturbed cells and cells where ash was not present under initial conditions, but species richness was different among all other groups-undisturbed/ disturbed, undisturbed/ash eradication, undisturbed/ash not present, and disturbed/ash eradication (pairwise Wilcoxon rank sum $p<0.05$ ) (Figure S6). Measuring species richness within climate scenarios showed that disturbance and ash loss had a significant influence on species richness in year 2100 .

\section{Influence of Climate on Biomass and Relative Abundance}

Of 2,024,335 cells on the landscape, only $80.1 \%$ had forest cover under initial conditions, but this expanded to $99.6 \%$ by the end of century. To account for differences in area at the beginning and end of the simulation, all results are reported on a per area $\left(\mathrm{g} / \mathrm{m}^{2}\right)$ or relative basis for interpretation of species-specific changes. Average biomass increased from $7651 \mathrm{~g} / \mathrm{m}^{2}$ in year 2000 to an average of $23,819 \mathrm{~g} / \mathrm{m}^{2}(S E=84.4)$ in year 2100 , largely explained by the fact that the average age of the forest at the beginning of the simulation was 53 years. At the landscape scale, all functional groups experienced an initial increase in average biomass; some functional groups, including north- ern hardwoods, southern conifers, southern hardwoods, and oaks, continued to increase in biomass through the century while others, including northern conifers, aspens, and birches, began to experience declines around the mid-century (Figure 3). Variation in end-of-century biomass was much more pronounced within some functional groups, including northern hardwoods, northern conifers, and birches, compared to aspens, oaks, southern hardwoods, and southern conifers (Figure 4). (For a full description of changes in average biomass throughout the century, see "Appendix D.")

The relative abundance of functional groups, or each functional group's proportional biomass compared to the total biomass of all species, expressed as a percentage, differed between 2000 and 2100 (Figure 5). Under both historical and climate change scenarios through 2100 , the relative proportion of northern hardwood biomass decreased by about $12 \%$ (from 47 to $35 \%$ of the total biomass of all species). However, the patterns of change of the relative declines in northern hardwoods were different between historical and future climate scenarios. Under historic climate, there were moderate declines in aspens and birches, as might be expected from successional dynamics, and moderate increases in southern hardwoods and conifers. In contrast, under the three future climate scenarios, the increases in southern hardwoods were twice that seen under historic climate scenarios, increasing from 4 to $23 \%$ by mid-Century.

Changes in functional group biomass differed spatially across the study area (Figure 6). For example, in the north of the study area (CR 13), northern hardwood biomass contributed $42 \%$ of the total biomass by year 2100 , but only $19 \%$ of the total biomass in the south (CR 32). In comparison, southern hardwoods became proportionally more abundant across the full landscape, increasing by $11-27 \%$ between 2000 and 2100 , and they became dominant in the south. As another example, aspens disappeared from the north (for example, CR 13) by the end of the century, decreasing from 11 to $0 \%$. Similarly, their proportional biomass at the landscape scale decreased by roughly $7 \%$ between years 2000 and 2100 . Aspens were largely maintained in the south (for example, CR 32), decreasing in proportional abundance by just $1 \%$.

Average species richness (number of species per hectare) increased over time across all scenarios, increasing from about 5 species/ha to between 7 and 9 species/ha by the end of century (Table 2). 


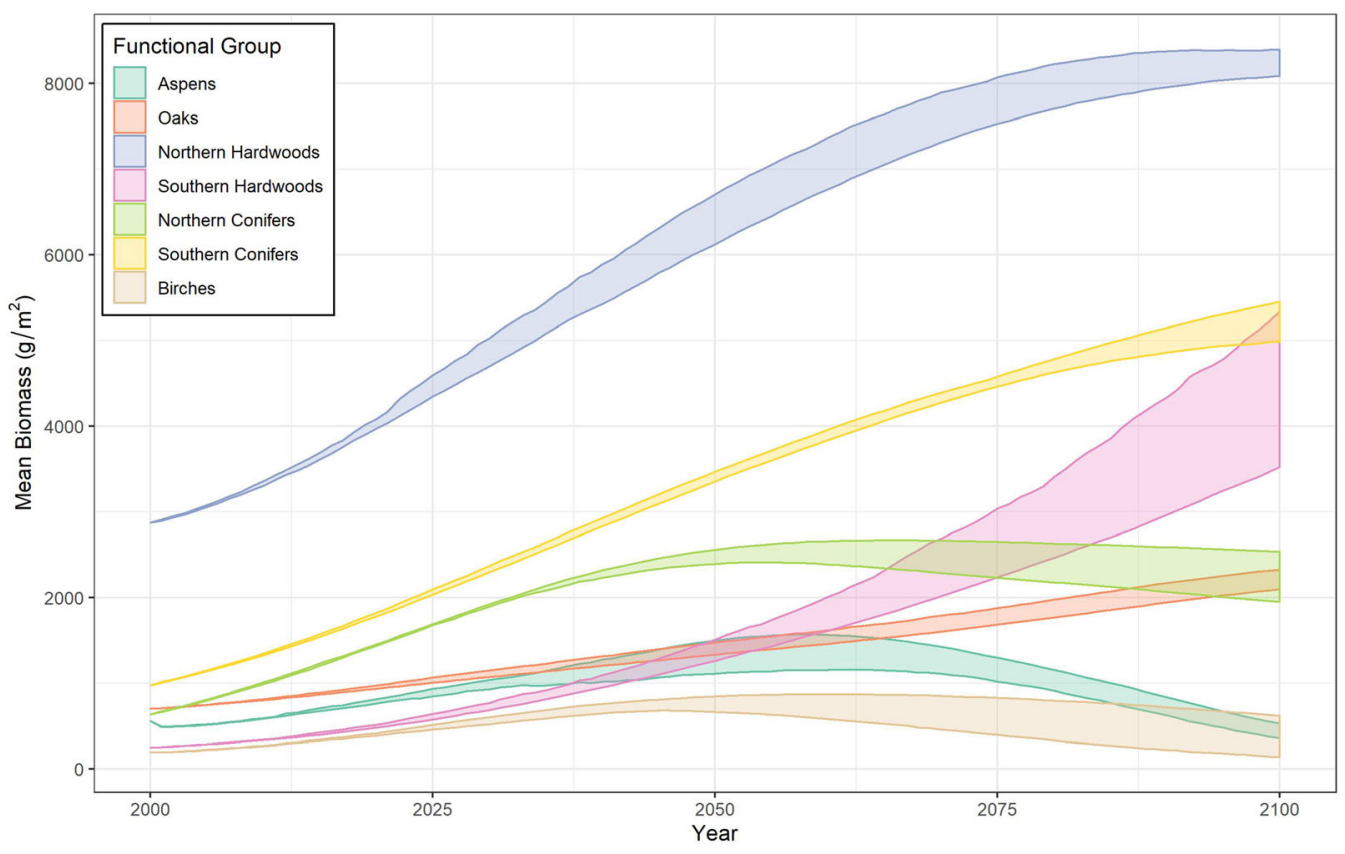

Figure 3. Change in average biomass $\left(\mathrm{g} / \mathrm{m}^{2}\right)$ through time by functional group aggregated across all climate scenarios at the landscape scale. Ribbons show the range between minimum and maximum values.

Species richness was highest under historic climate conditions and lowest under the hot/variable precipitation future climate scenario. Species richness was lower in 2050 compared to $2100(W=0$, $p<<0.05)$, and differed among climate scenarios in both years (Kruskal-Wallis $\mathrm{X}^{2}=17.58, \mathrm{df}=3$, $p<<0.05$; Kruskal-Wallis $\mathrm{X}^{2}=17.86, \mathrm{df}=3$, $p<<0.05$, respectively).

Many species that were abundant initially remained abundant through the simulation (for example, basswood, red maple, red oak, sugar maple, white cedar, and white pine, as well as red pine under historic climate conditions); similarly, species that were least abundant remained least abundant (American beech, bitternut hickory, butternut, and shag hickory, as well as red cedar under historic climate conditions and willows under future climate conditions) (Table 3). Species that gained dominance on the landscape under all climate scenarios included black cherry and yellow birch, whereas white oak and tamarack became dominant under select climate scenarios (Table 3). Species that decreased in abundance on the landscape and became the least abundant under all climate scenarios included black spruce, bur oak, green ash, and silver maple (Table 3). Pin oak, which is currently one of the most abundant species on the landscape, became one of the least abundant species by 2100 under the future climate scenarios (Table 3 ).

\section{Discussion}

Our results are largely consistent with our overall expectations regarding shifts in functional group biomass over the next century (Table S2), with a few notable exceptions discussed below. The general increase in total biomass over time is to be expected given that the forest is fairly young, having recently experienced the cessation of intensive logging coupled with agricultural abandonment (Rhemtulla and others 2009). The initial increase in the biomass of all functional groups that we simulated is consistent with other studies that demonstrate "landscape inertia" in the region, or a continuation of current growth trends in the short term (Janowiak and others 2014). Thus, the overall increase in biomass across most functional groups is most likely due to maturing trees and new establishment, coupled with the fact that other disturbances, such as wind, fire, and non-ash harvest, were not simulated in our study.

However, the overall increase in landscape-level biomass hides important forest reorganization dynamics that occur in the latter half of the century. By mid-century, certain functional groups, including northern conifers, aspens, and birches, began to experience declines in biomass. By the end of the century, these three groups constitute the three least abundant functional groups on the landscape under future climate change scenarios. Meanwhile, northern hardwoods, southern hard- 

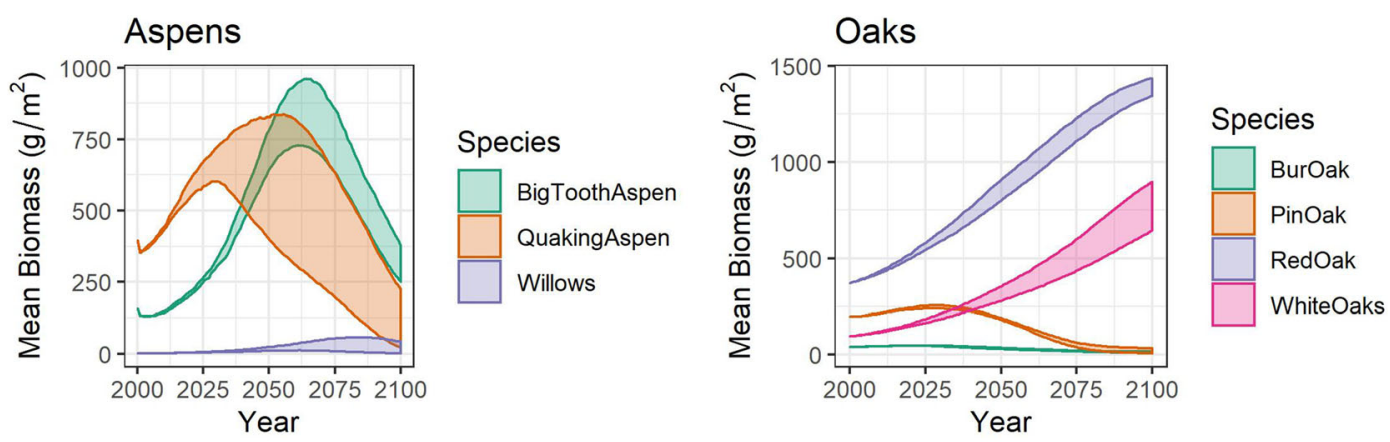

Northern Hardwoods 1

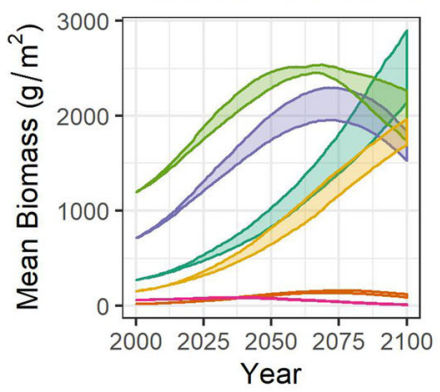

\section{Species}
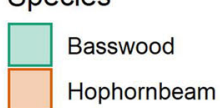
RedMaple SilverMaple SugarMaple YellowBirch

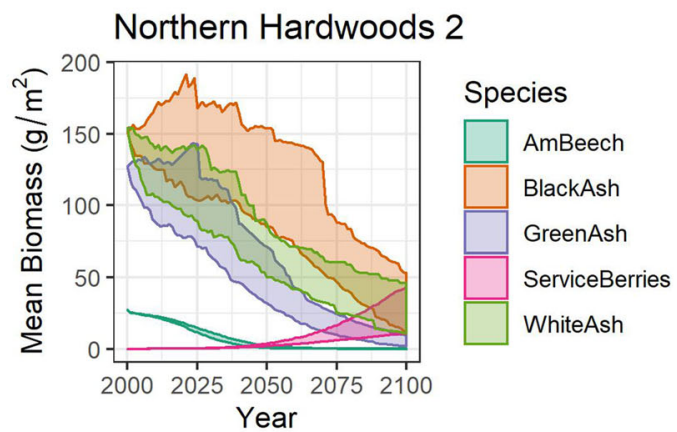

Southern Hardwoods
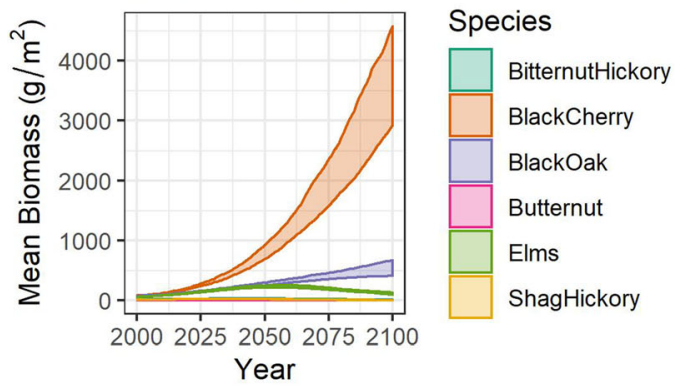

Northern Conifers

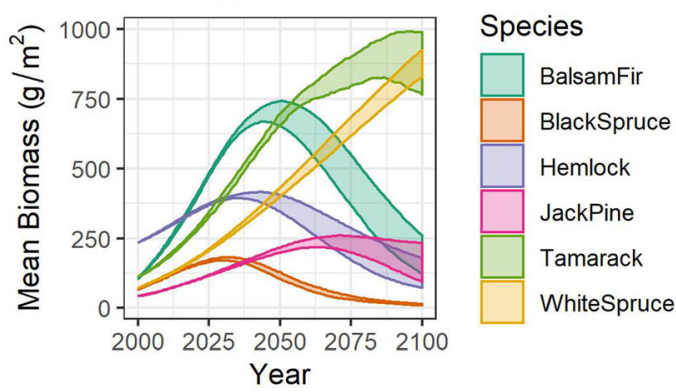

Southern Conifers

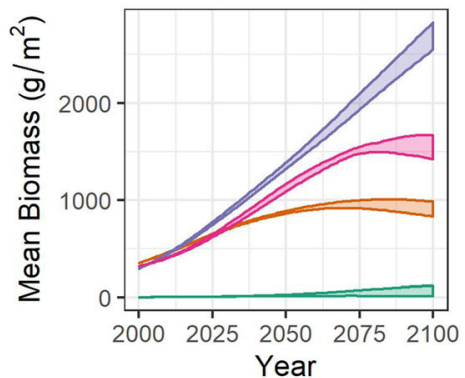

Species
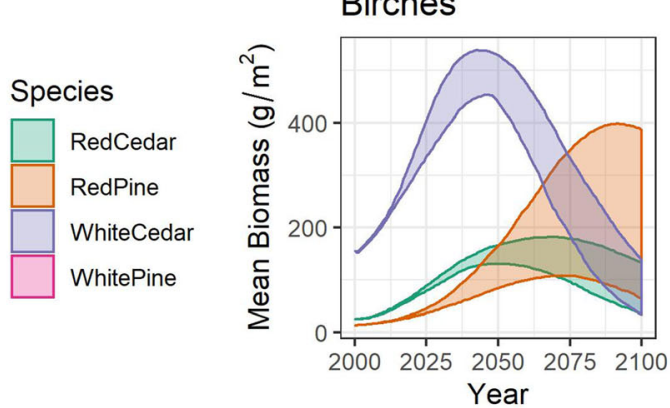

Species

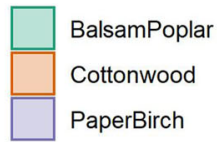

Figure 4. Change in average biomass $\left(\mathrm{g} / \mathrm{m}^{2}\right)$ through time of each species, organized by functional group, aggregated across all climate scenarios at the landscape scale. Ribbons show the range between minimum and maximum values. Note: Northern hardwoods are broken down into two groups for clarity. Note: $Y$-axis scales are different.

woods, southern conifers, and oaks continue to increase in biomass beyond the mid-century. Thus, we observed a trend toward a greater abundance of species that prefer warmer conditions coupled with decreasing proportional abundances of those species that are not well adapted to hot conditions with occasional periods of water scarcity.
End-of-century dominance by a given species, regardless of functional group, may be attributed to one or more factors, and may not be driven by climate alone. These factors may include: (1) an abundance of that species in the understory of ashdominant or ash-associate cells, whereby ash mortality and canopy opening lead to release; (2) 


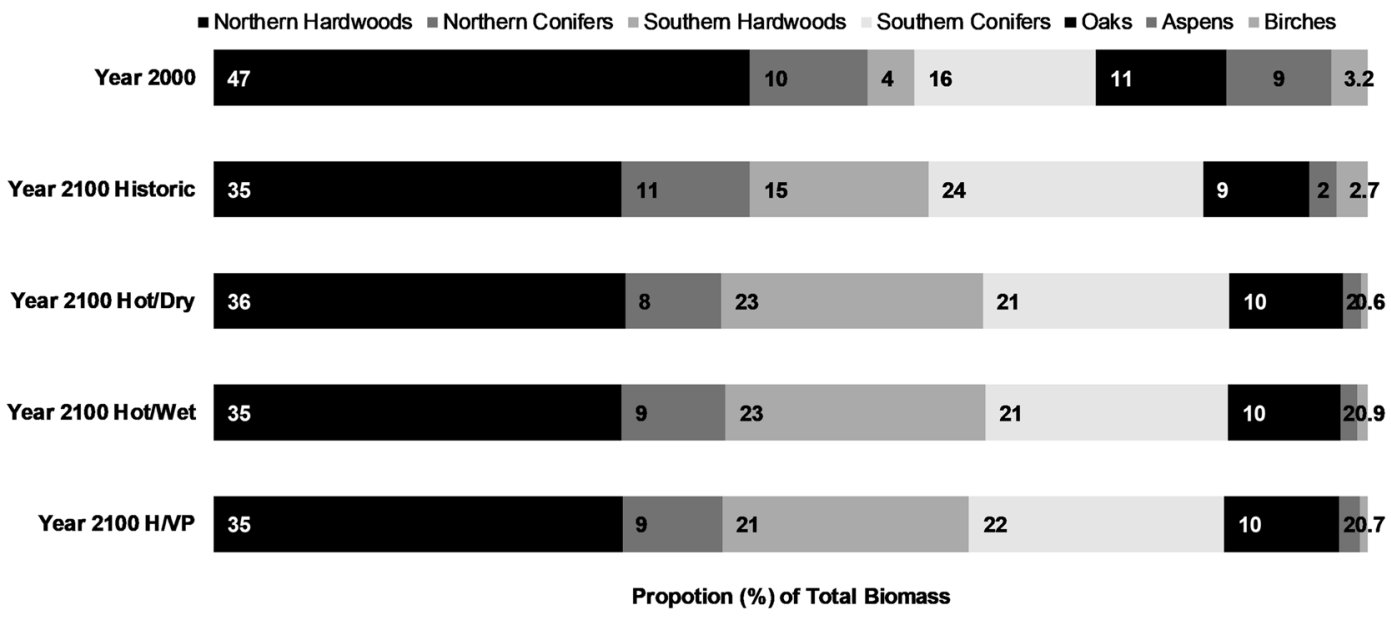

Figure 5. Functional group biomass as a percent of total biomass $\left(\mathrm{g} / \mathrm{m}^{2}\right)$ at the beginning (Year 2000) and end of the simulation (Year 2100) under four climate scenarios, measured at the landscape scale. Note that overall biomass on the landscape increases over the century.

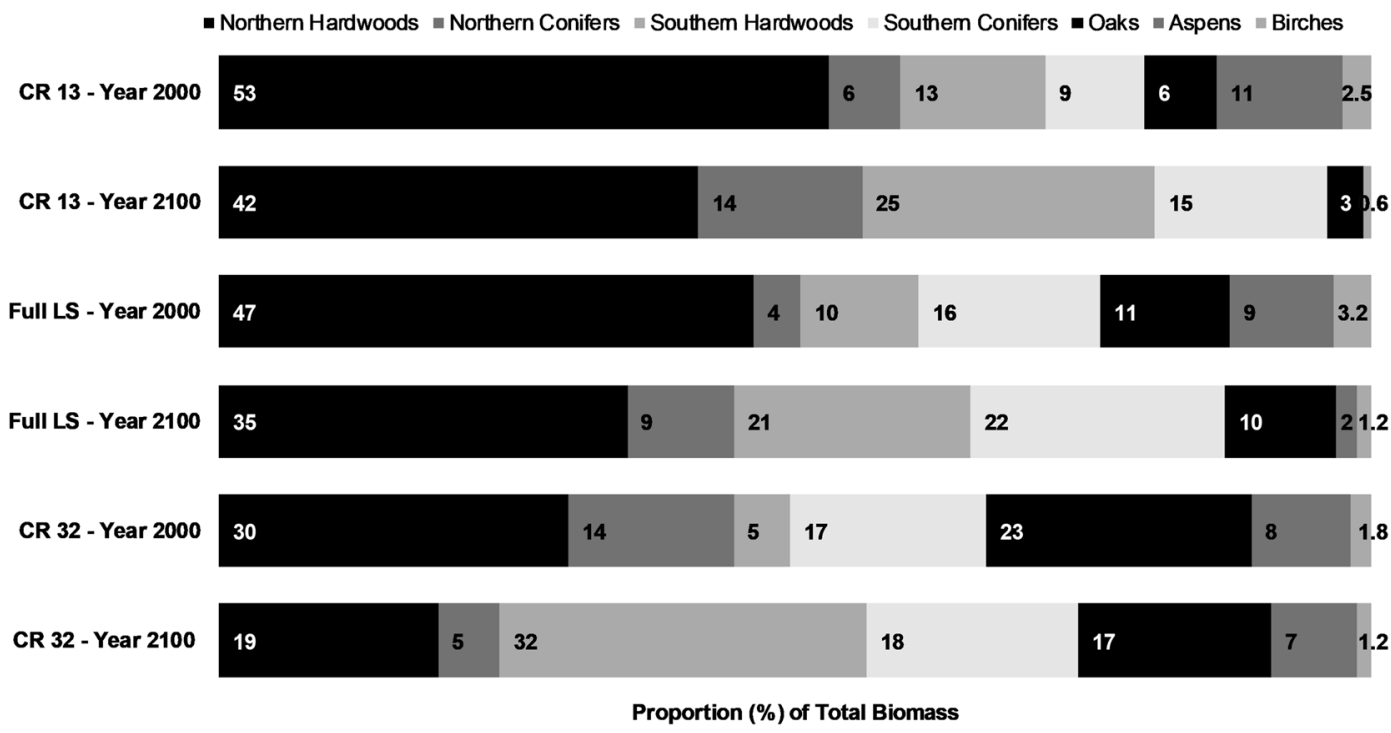

Figure 6. Functional group biomass as a percent of total biomass $\left(\mathrm{g} / \mathrm{m}^{2}\right)$ at the beginning (Year 2000) and end of the simulation (Year 2100) in regions of climatic extremes (climate region (CR 13 in the north and CR 32 in the south), and at the landscape scale (Full LS), aggregated across historic and future climate scenarios.

Table 2. Average Species Richness, or Number of Species per Hectare, Measured at the Landscape Scale

\begin{tabular}{lllr}
\hline Climate scenario & \multicolumn{2}{c}{ Year } & \\
\cline { 2 - 4 } & $\mathbf{2 0 0 0}$ & 2050 & 2100 \\
\hline Historic & 4.79 & $7.51( \pm 0.07)$ & $8.96( \pm 0.07)$ \\
Hot/Dry & 4.79 & $7.05( \pm 0.04)$ & $7.83( \pm 0.002)$ \\
Hot/Wet & 4.79 & $7.34( \pm 0.005)$ & $8.45( \pm 0.005)$ \\
HTVP & 4.79 & $7.08( \pm 0.01)$ & $7.79( \pm 0.009)$
\end{tabular}

Within and between-year average values are all significantly different $(p<0.05)$. Numbers in parenthesis are standard deviations. 
Table 3. Most and Least Abundant Species by Average Biomass $\left(\mathrm{g} / \mathrm{m}^{2}\right)$ in Years 2000 and 2100 Across All Climate Scenarios

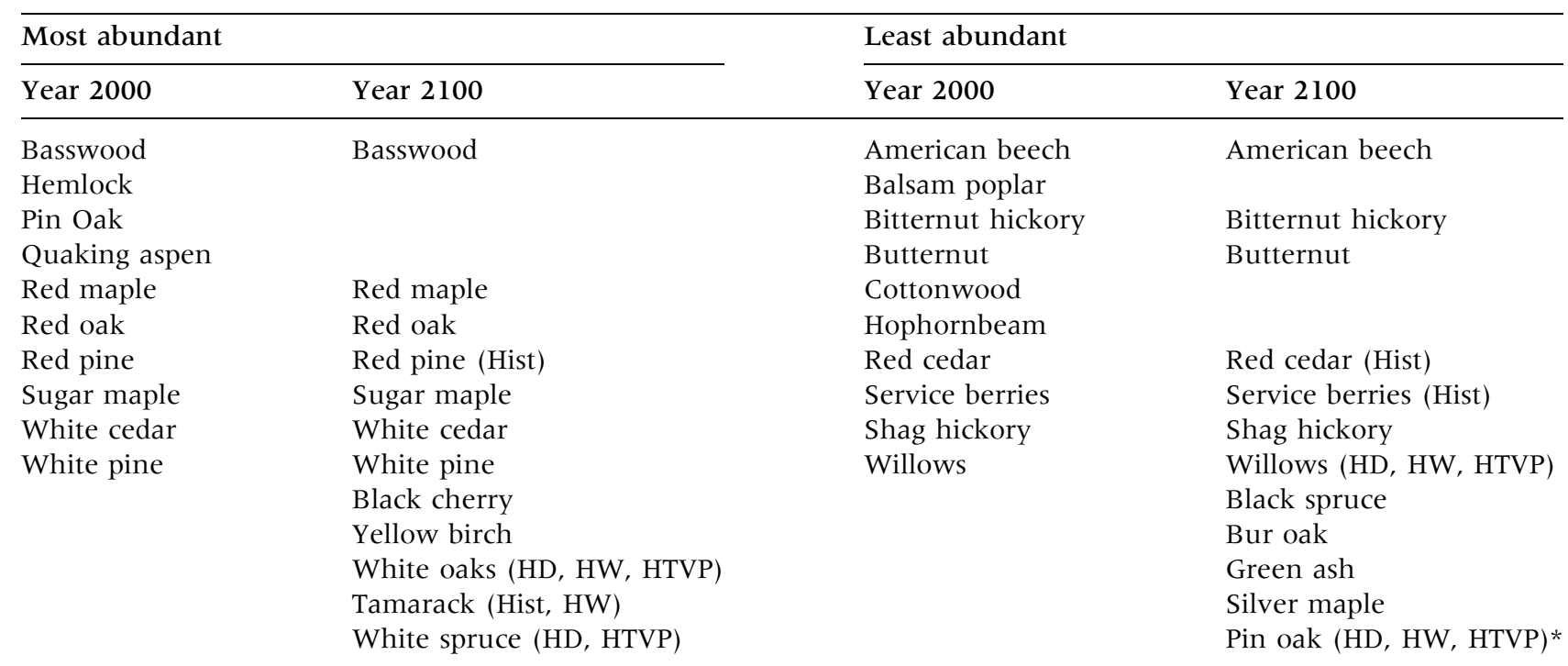

\footnotetext{
"Pin oak was one of the most abundant species in year 0 and was almost always one of the least abundant species in year 100.

For those that are most and least abundant depending on the scenario, the scenarios in which they fall into that category are listed in the parentheses (Hist = historic, $H D=$ hot/dry, HW = hot/wet, HTVP = hot/variable precipitation). Species that remained one of the most or least abundant through time are indicated as such through matching their locations in the Year 2000 and Year 2100 columns. Species list ordering does not represent relative abundance.
}

that species being already dominant or sub-dominant in non-ash cells, whereby unhindered succession (lack of disturbance) favors the continued growth of that species; or (3) that species' range shifting into previously uninhabitable areas via climatic variation, whereby the species' increase in biomass is attributed primarily to an increase or change in extent. Although it is difficult to disentangle the drivers of species dominance, which are occurring simultaneously in the model, our results strongly suggest these interactions among climate, succession, and disturbance cannot be ignored when making projections about forest reorganization in the future.

These complex interactions, largely a response to species-specific life-history parameterizations, led to emergent behaviors at the species level. Our results showed a nearly exponential increase in black cherry biomass, which is supported by recent work exploring wind disturbance in the region (Lucash and others 2019) but contradicts other studies (Janowiak and others 2014). Our results may be attributed to the fact that black cherry tended to have greater end-of-century biomass in disturbed sites, with slight variation due to climate change. Black cherry does exceptionally well in secondary succession conditions due to its combined ability to persist in abundance in the understory and grow rapidly when canopy openings occur (USDA 2020). It has also been found that black cherry is one of the most abundant species in the seedling strata in gaps formed by EAB-caused ash mortality and in forested areas surrounding those gaps (Engelken and others 2020). Similarly, black cherry is often dominant in the forests surrounding ash gaps and represents a major component of the sapling strata (Engelken and others 2020). Indeed, a potential shift from red oak dominance to red maple and black cherry dominance has been observed in eastern forests as a result of forest mesophication following a decline in fire frequency over the last century (Engelken and others 2020). Further, in an analysis of candidate trees suitable for black ash replacement, black cherry was categorized as one of the most promising replacement species because of its present association with black ash and its ability to adapt reasonably well to future climate conditions (Iverson and others 2016). Thus, the end-of-century black cherry biomass that we observed here may be attributed to a combination of landscape inertia, favorable climate conditions, and EAB-related disturbance.

As another example, we expected northern conifers in general to decrease in biomass over the next century, but two species-tamarack and white spruce-increased. The increase in white spruce biomass contradicts other work that projected a near extirpation of this species under climate change conditions (Scheller and Mladenoff 2005). 
However, both tamarack and white spruce are commonly found in wet, poorly drained swampy areas where black ash is also often found (USDA 2020). Tamarack and white spruce both rapidly colonize disturbed sites. Thus, declines in tamarack and white spruce biomass, which would be expected under warming conditions and uncertain precipitation patterns, might be mitigated by widespread black ash mortality in the coming century. In particular, tamarack might benefit from mortality of young black ash trees in sites where both species become established, thereby gaining dominance through competitive exclusion. However, tamarack is also subject to mortality from native and non-native insect species, namely eastern larch beetle (Dendroctonus simplex LeConte) and tamarack sawfly (Pristiophora erichsonii Hartig), respectively (Janowiak and others 2014; WIDNR 2018). Climate-related stressors, such as drought and prolonged exposure to water due to flooding, can weaken tamarack trees and make them more vulnerable to beetle and sawfly infestation (Janowiak and others 2014; WIDNR 2018). Thus, future warming trends, as well as other confounding factors, might hinder Tamarack growth and alter successional pathways in novel ways. Further, it has been suggested that gaps caused by EAB-related ash mortality might be rapidly transitioning to sedge-dominated meadows as the opportunistic species prevents adequate recruitment of potential overstory tree species (Engelken and others 2020). Areas that contain only one species of ash, such as black ash stands in the Laurentian Mixed Forest province, may be particularly vulnerable to this type of threat (Granger and others 2019).

The loss of ash species has additional management and cultural implications in the region. For example, sustainable yield management practices of the Menominee Indian Tribe of Wisconsin have resulted in a highly productive and biodiverse forest, supporting 2360 cubic meters of standing sawlog volume and 33 tree species (Mausel and others 2016). EAB represents just one of many threats to the Menominee forest, but its potential impact extends beyond that of economic or aesthetic damages; indeed, ash trees are a cultural resource for the Menominee and their use involves many lessons from traditional ecological knowledge (Anon 2017). Current tribal management plans speak to the importance of finding ways to preserve black ash for basket weaving and other traditional arts, as well as white ash for woodworking and traditional uses such as lacrosse sticks and snowshoes (Menominee Tribal Enterprises 2018). Further, because the Menominee world- view holds that the natural environment includes humans, the health of the people is connected to the health of the forest and other beings; thus, $\mathrm{EAB}$ poses a threat to the health and well-being of the entire Menominee community (Dockry and others 2016; Anon 2017). Tribal decisions regarding ongoing forest management thus recognize that Indigenous livelihoods are uniquely threatened by the compound effects of climate change and the continued presence of institutional barriers, which are maintained through ongoing settler colonial oppression (Dockry and others 2016; Whyte and others 2018; USGCRP 2018).

\section{Caveats}

Importantly, to isolate the ecological response of the forest to near complete ash removal, EAB invasion and ash harvest were the only disturbances simulated on the landscape over the next century. We assumed that EAB will continue to cause widespread and relatively rapid ash mortality in the study region over the coming century, regardless of host age or biophysical setting. There is a chance that the spread of EAB will be impeded by county-level timber quarantines and other management practices (Cappaert and others 2005; Poland and Mccullough 2010; Barlow and others 2014; Herms and McCullough 2014). Yet at present, it is highly likely that EAB will cause extensive ash mortality in the study region (Krist Jr. and others 2014). In addition, other natural and human disturbances were not included. Wind events, ranging in scale from single tree blowdowns to extensive tornado damage, are a large component of the region's natural disturbance regime (Janowiak and others 2014) and have been shown elsewhere to influence species dynamics and resilience (Lucash and others 2019). Apart from EAB, other pests and pathogens, both native and invasive, also affect forests in the study region. These include jack pine budworm, spruce budworm, gypsy moth, oak wilt, butternut canker, and earthworms, among others (Janowiak and others 2014). Furthermore, LANDIS-II does not incorporate insect physiology, which often interacts with tree physiology to alter the host-agent interaction in complex and novel ways. Research on EAB-ash interactions has found that factors such as bark roughness and phloem chemistry can alter a potential host tree's susceptibility to EAB infestation (Marshall and others 2013; Herms and McCullough 2014). Vegetation-wildlife interactions, such as deer browsing, also alter succession dynamics, especially in the early stages of estab- 
lishment in both early- and late-successional stands in this region. Forest timber products contribute greatly to the economy in the region (Janowiak and others 2014), meaning forest management and harvest occur at diverse spatial scales, representing a range of ownership types and jurisdictional boundaries. Further, land use change is constantly occurring, and the impacts of urbanization or other land use pressures were not included here. It is important to consider the exclusion of these processes from this work when interpreting the results, as complex interactions between such processes at multiple spatial and temporal scales are likely to influence future forest structure and function. In addition, we recognize the difference in forest history for certain forests within the region, namely those on tribal lands, and seek to develop opportunities to continue to adjust this study to fit more on the ground examples in the future. Indeed, using sustainable forest management practices outlined by Menominee Tribal Enterprises to parameterize harvest on one part of the landscape represents just one of many management scenarios in a landscape that has a diversity of land use histories. Incorporating multiple forest management plans, such as those of private and public forest land managers, which usually include many and various harvest and planting strategies, was beyond the scope of this study. The highly targeted harvest scenario we used in this study, which is part of a comprehensive management plan, was used intentionally to highlight some of the potential ecological impacts of ash removal alone. While our results show that ash removal, due to either harvest or EAB-related mortality, has limited implications for forest structure and composition over the coming century, it is important to note that there are other consequences of ash removal not explored in this research. These include changes in resource availability for certain fauna; changes in microclimate, biogeochemical cycling, and hydrological regimes; and altered carbon fluxes through a reduction in net primary productivity. Further, the magnitude of these changes might depend on sitespecific conditions, including extant species diversity, as well as canopy and cohort diversity in stands containing ash (Granger and others 2019). For example, due to its tendency to be a foundational, keystone, and dominant species where it occurs, black ash stands might require considerably more ecological consideration in management plans (Looney and others 2015; Granger and others 2019). Meanwhile, the loss of white and green ash might have greater economic than ecological impacts, meaning mitigation plans for these species might need only consider which species serve as suitable alternatives that are comparable in timber value (Granger and others 2019). For more nuanced approaches to ash management and potential replacement species, we point to (Looney and others 2015; Nisbet and others 2015; Iverson and others 2016; Granger and others 2019). Thus, there are many complex interactions that while not explored here, present important opportunities for future research. However, our results contribute meaningfully to the $\mathrm{EAB}$ and forest ecology literature by highlighting the potential effects of one highly specialized and targeted form of disturbance on forest composition and diversity.

\section{ConClusion}

Overall, our results highlight the critical interaction between expected changes in climate and disturbance on biodiversity over the next century, showing greater homogenization of the landscapelevel species assemblage and greater inequality in each functional group's proportional share of biomass compared to the historic condition. In particular, southern hardwoods and oaks account for a greater amount of proportional biomass, while northern conifers, southern conifers, aspens, and birches account for less of the proportional biomass under future climate scenarios compared to the historic scenario. Moreover, despite an abundance of concern over the loss of ash trees due to widespread $\mathrm{EAB}$ invasion, we find limited evidence to suggest that ash loss will impact species dominance and richness in our study region. End-of-century biomass is not a function of ash loss, and those species that come to dominate the landscape are not found exclusively in areas where ash loss occurred. Further, there is no difference in the response of species richness to disturbance compared to areas where ash was not present under the initial condition. Together, these results suggest that ash loss will not be a primary driver of forest change over the next century at landscape scales. However, the loss of ash may have negative consequences for other biophysical processes, including hydrologic regimes in swampy areas dominated by black ash and may have significant negative consequences as a cultural resource, such as to the Menominee. Evidence of its negative economic and ecological impacts is broadly understood, and there is a general consensus that $\mathrm{EAB}$ will continue to have negative impacts on ecosystem processes. As $E A B$ continues to become established in new areas, $\mathrm{EAB}$ management remains an active area of research and regulation. 


\section{ACKNOWLEDGEMENTS}

This research was supported by The National Science Foundation Award No. 1617396, the National Aeronautics and Space Agency Pennsylvania Space Grant Consortium, the Earth and Environmental Systems Institute, the Center for Landscape Dynamics, as well as the E. Willard Miller Award in Geography, the Herbert and Mary B. Hughes Fund, and The Pennsylvania State University Department of Geography. Data used in or part of this publication were made possible, in part, by an agreement from the United States Department of Agriculture's Forest Service (FS). Any opinions, findings, and conclusions or recommendations expressed in this publication are those of the authors and do not necessarily reflect the views of the National Science Foundation, the National Aeronautics and Space Association, the U.S. Forest Service, or any other funding agencies. We would like to thank Jared Oyler for his assistance in preparing the climate forcing data, and Jamie Peeler for assistance with Figures 1 and 2 .

\section{OPEN ACCESS}

This article is licensed under a Creative Commons Attribution 4.0 International License, which permits use, sharing, adaptation, distribution and reproduction in any medium or format, as long as you give appropriate credit to the original author(s) and the source, provide a link to the Creative Commons licence, and indicate if changes were made. The images or other third party material in this article are included in the article's Creative Commons licence, unless indicated otherwise in a credit line to the material. If material is not included in the article's Creative Commons licence and your intended use is not permitted by statutory regulation or exceeds the permitted use, you will need to obtain permission directly from the copyright holder. To view a copy of this licence, visit $\mathrm{h}$ ttp://creativecommons.org/licenses/by/4.0/.

\section{REFERENCES}

Abatzoglou JT, Brown TJ. 2012. A comparison of statistical downscaling methods suited for wildfire applications. International Journal of Climatology 32:772-780.

Agius AC, McCullough DG, Cappaert DG. 2005. Host range and preference of the emerald ash borer in North America: Preliminary results. In: Mastro V, Reardon R, Eds. Emerald ash borer research and technology development meeting, p 28-29, . Forest Health Technology Enterprise Team: Romulus (MI).

Anderson B. 2005. The historical development of the tension zone concept in the Great Lakes region of North America. The Michigan Botanist 44:127-138.
Anderson T, Dragicevic S. 2016. A geosimulation approach for data scarce environments: Modeling dynamics of forest insect infestation across different landscapes. ISPRS International Journal of Geo-Information 5(2):9.

Anon. 2017. Measuring the pulse of the forest. College of Menominee Nation. 483 p.

Anulewicz AC, McCullough DG, Cappaert DL. 2007. Emerald ash borer (Agrilus planipennis) density and canopy dieback in three North American ash species. Arboriculture and Urban Forestry 33(5):338-349.

Barlow L-A, Cecile J, Bauch CT, Anand M. 2014. Modelling interactions between forest pest invasions and human decisions regarding firewood transport restrictions. PLOS ONE 9:112.

BenDor TK, Metcalf SS, Fontenot LE, Sangunett B, Hannon B. 2006. Modeling the spread of the Emerald Ash Borer. Ecological Modelling 197(1-2):221-236.

Bossenbroek J, Croskey A, Finnoff D, Iverson L, McDermott SM, Prasad A, Sims C, Sydnor D. 2015. Evaluating the economic costs and benefits of slowing the spread of emerald ash borer in Ohio and Michigan. In: Keller RP, Cadotte MW, Sandiford G, Eds. Invasive species in a globalized world: ecological, social, and legal perspectives on policy, 1st edn. Chicago, IL: University of Chicago Press. pp 85-208.

Burns RM, Honkala BH. 1990. Silvics manual volume 2: Hardwoods. Washington DC: USDA Forest Service.

Cappaert D, McCullough DG, Poland TM, Siegert NW. 2005. Emerald ash borer in North America: A research and regulatory challenge. American Entomologist 51:152-165.

Costanza KKL, Livingston WH, Kashian DM, Slesak RA, Tardif JC, Dech JP, Diamond AK, Daigle JJ, Ranco DJ, Neptune JS, Benedict L, Fraver SR, Reinikainen M, Siegert NW. 2017. The precarious state of a cultural keystone species: Tribal and biological assessments of the role and future of black ash. Journal of Forestry 115(5):435-446.

Curtis JT. 1959. The vegetation of Wisconsin: An ordination of plant communities. Madison Wisconsin USA: The University of Wisconsin Press.

D'Amato AW, Palik BJ, Slesak RA, Edge G, Matula C, Bronson DR. 2018. Evaluating adaptive management options for black ash forests in the face of emerald ash borer invasion. Forests $9(6): 348$.

Dockry MJ, Hall K, Van Lopik W, Caldwell CM. 2016. Sustainable development education, practice, and research: an indigenous model of sustainable development at the College of Menominee Nation, Keshena, WI, USA. Sustainability Science 11:127-138.

Engelken PJ, Benbow ME, McCullough DG. 2020. Legacy effects of emerald ash borer on riparian forest vegetation and structure. Forest Ecology and Management 457:117684.

Flower CE, Knight KS, Gonzalez-Meler MA. 2013. Impacts of emerald ash borer (Agrilus planipennis Fairmaire) induced ash (Fraxinus spp.) mortality on forest carbon cycling and successional dynamics in the eastern United States. Biological Invasions 15:931-944.

Gandhi KJK, Herms DA. 2010. Direct and indirect effects of alien insect herbivores on ecological processes and interactions in forests of eastern North America. Biological Invasions 12:389405.

Granger JJ, Zobel JM, Buckley DS. 2019. Differential impacts of emerald ash borer (Agrilus planipennis Fairmaire) on forest 
communities containing native ash (Fraxinus spp.) species in eastern North America. Forest Science 66:38-48.

Gustafson EJ, Shifley SR, Mladenoff DJ, Nimerfro KK, He HS. 2000. Spatial simulation of forest succession and timber harvesting using LANDIS. Canadian Journal of Forest Research 30:32-43.

Gustafson EJ, De Bruijn A, Lichti N, Jacobs DF, Sturtevant BR, Foster J, Miranda BR, Dalgleish HJ. 2017. The implications of American chestnut reintroduction on landscape dynamics and carbon storage. Ecosphere 8:1-21.

Herms DA, McCullough DG. 2014. Emerald ash borer invasion of North America: History, biology, ecology, impacts, and management. Annual Review of Entomology 59:13-30.

Hijmans RJ. 2019. Raster: Geographic data analysis and modeling. https://cran.r-project.org/package=raster.

Iverson L, Knight KS, Prasad A, Herms DA, Matthews S, Peters M, Smith A, Hartzler DM, Long R, Almendinger J. 2016. Potential species replacements for black ash (Fraxinus nigra) at the confluence of two threats: emerald ash borer and a changing climate. Ecosystems 19:248-270.

Janowiak MK, Iverson LR, Mladenoff DJ, Peters E, Wythers KR, Xi W, Brandt LA, Butler PR, Handler SD, Shannon D, Swanston C, Parker LR, Amman AJ, Bogaczyk B, Handler C, Lesch E, Reich PB, Matthews S, Peters M, Prasad A, Khanal S, Liu F, Bal T, Bronson D, Burton A, Ferris J, Fosgitt J, Hagan S, Johnston E, Kaen E, Matula C, O'Connor R, Higgins D, St. Pierre M, Daley J, Davenport M, Emery MR, Fehringer D, Hoving CL, Johnson G, Neitzel D, Notaro M, Rissman A, Rittenhouse C, Ziel R. 2014. Forest ecosystem vulnerability assessment and synthesis for northern Wisconsin and western Upper Michigan: A report from the Northwoods Climate Change Response Framework Project. General Technical Report NRS-136. Newtown Square (PA). 247p.

Kassulke N, Mladenoff DJ. 2010. Ecological history of Wisconsin's forests. In: Statewide Forest Action Plan Part I: Statewide Forest Assessment 2010. Madison, WI: Wisconsin Department of Natural Resources, Division of Forestry.

Klooster WS, Herms DA, Knight KS, Herms CP, McCullough DG, Smith A, Gandhi KJK, Cardina J. 2014. Ash (Fraxinus spp.) mortality, regeneration, and seed bank dynamics in mixed hardwood forests following invasion by emerald ash borer (Agrilus planipennis). Biological Invasions 16:859-873.

Klooster WS, Gandhi KJK, Long LC, Perry KI, Rice KB, Herms DA. 2018. Ecological impacts of emerald ash borer in forests at the epicenter of the invasion in North America. Forests 9 (250).

Knight KS, Brown JP, Long RP. 2013. Factors affecting the survival of ash (Fraxinus spp.) trees infested by emerald ash borer (Agrilus planipennis). Biological Invasions 15:371-383.

Kolka RK, D'Amato AW, Wagenbrenner JW, Slesak RA, Pypker TG, Youngquist MB, Grinde AR, Palik BJ. 2018. Review of ecosystem level impacts of emerald ash borer on black ash wetlands: What does the future hold? Forests 9(4):179.

Krist Jr. FJ, Ellenwood JR, Woods ME, McMahan AJ, Cowardin JP, Ryerson DE, Sapio FJ, Zweifler MO, Romero SA. 2014. FHTET-14-01: 2013-2027 National insect and disease forest risk assessment. Forest Health Technology Enterprise Team, U.S. Forest Service, Fort Collins (CO). 199p.

Kucharik C. 2013. Patterns of climate change across Wisconsin from 1950-2006. Journal of Physical Geography 31(1):1-28.

Kurtz CM, Dahir SE, Stoltman AM, McWilliams WH, Butler BJ, Nelson MD, Morin RS, Piva RJ, Herrick SK, Lorentz LJ, Guthmiller M, Perry CH. 2017. Wisconsin Forests 2014. Re- source Bulletin NRS-112, U.S. Department of Agriculture, Forest Service, Northern Research Station. Newtown Square (PA). $116 \mathrm{p}$.

Liang L, Fei S. 2014. Divergence of the potential invasion range of emerald ash borer and its host distribution in North America under climate change. Climatic Change 122(4):735746.

Looney CE, D'Amato AW, Palik BJ, Slesak RA. 2015. Overstory treatment and planting season affect survival of replacement tree species in emerald ash borer threatened Fraxinus nigra forests in Minnesota, USA. Canadian Journal of Forest Research 45:1728-1738.

Lovett GM, Canham CD, Arthur MA, Weathers KC, Fitzhugh RD. 2006. Forest ecosystem responses to exotic pests and pathogens in eastern North America. Bioscience 56:395-405.

Lucash MS, Scheller RM. 2019. LANDIS-II Climate Library v4.0 User Guide. 13p.

Lucash MS, Scheller RM, Kretchun AM, Clark KL, Hom J. 2014. Impacts of fire and climate change on long-term nitrogen availability and forest productivity in the New Jersey Pine Barrens. Canadian Journal Forest Research 44:404-412.

Lucash MS, Scheller RM, Gustafson EJ, Sturtevant BR. 2017. Spatial resilience of forested landscapes under climate change and management. Landscape Ecology 32(5):953-969.

Lucash MS, Ruckert KL, Nicholas RE, Scheller RM, Smithwick EAH. 2019. Complex interactions among climate and successional trajectories govern spatial resilience after severe windstorms in central Wisconsin, U.S.A. Landscape Ecology 34:2897-2915.

Marshall JA, Smith EL, Mech R, Storer AJ. 2013. Estimates of Agrilus planipennis infestation rates and potential survival of ash. The American Midland Naturalist 169:179-193.

Mausel DL, Waupochick A, Pecore M. 2016. Menominee forestry: Past, present, future. Journal of Forestry 115:366-369.

Menominee Tribal Enterprises. 2012. Forest Management Plan (1973 Revision). Keshena, Wisconsin, U.S.A.

Menominee Tribal Enterprises. 2018. Emerald ash borer IPM plan, http://www.mtewood.com/SustainableForestry/EABPla n, Accessed online August 13, 2020.

Mercader RJ, Siegert NW, Liebhold AM, McCullough DG. 2009. Dispersal of the emerald ash borer, Agrilus planipennis, in newly-colonized sites. Agricultural and Forest Entomology $11: 421-424$.

Mercader RJ, Siegert NW, Liebhold AM, McCullough DG. 2011. Simulating the effectiveness of three potential management options to slow the spread of emerald ash borer (Agrilus planipennis) populations in localized outlier sites. Canadian Journal of Forest Research 41:254-264.

Mladenoff DJ. 2004. LANDIS and forest landscape models. Ecological Modelling 180:7-19.

Morin RS, Liebhold AM, Pugh SA, Crocker SJ. 2017. Regional assessment of emerald ash borer, Agrilus planipennis, impacts in forests of the Eastern United States. Biological Invasions 19(2):703-711.

Muirhead JR, Leung B, Overdijk C, Kelly DW, Nandakumar K, Marchant KR, MacIsaac HJ. 2006. Modelling local and longdistance dispersal of invasive emerald ash borer Agrilus planipennis (Coleoptera) in North America. Diversity and Distributions 12:71-79.

Nisbet D, Kreutzweiser D, Sibley P, Scarr T. 2015. Ecological risks posed by emerald ash borer to riparian forest habitats: A re- 
view and problem formulation with management implications. Forest Ecology and Management 358:165-173.

Perry CH (Hobie), Everson VA, Brown IK, Cummings-Carlson J, Dahir SE, Jepsen EA, Kovach J, Labissoniere MD, Mace TR, Padley EA, Rideout RB, Butler BJ, Crocker SJ, Likens GC, Morin RS, Nelson MD, Wilson BT (Ty), Woodall CW. 2008. Wisconsin's forests, 2004. Resource Bulletin NRS-23, USDA Forest Service, Northern Research Station, Newtown Square (PA).

Poland TM, McCullough DG. 2010. SLAM: A multi-agency pilot project to slow ash mortality caused by emerald ash borer in outlier sites. Newsletter of the Michigan Entomological Society 55( 1 \& 2$): 4-8$.

Prasad AM, Iverson LR, Peters MP, Bossenbroek JM, Matthews SN, Sydnor TD, Schwartz MW. 2010. Modeling the invasive emerald ash borer risk of spread using a spatially explicit cellular model. Landscape Ecology 25:353-369.

R Core Team. 2018. R: A language and environment for statistical computing. https://www.r-project.org/.

Rabaglia B, Chaloux P. 2011. National response framework for emerald ash borer. United States Department of Agriculture, Forest Service, Animal Plant Health Inspection Service, National Associate of State Foresters, and the National Plant Board.

Rhemtulla JM, Mladenoff DJ, Clayton MK. 2009. Legacies of historical land use on regional forest composition and structure in Wisconsin, USA (mid-1800s-1930s-2000s). Ecological Applications 19:1061-1078.

RStudio Team. 2016. RStudio: Integrated development for R. RStudio, PBC, Boston, MA URL http://www.rstudio.com/.

Scheller RM, Mladenoff DJ. 2005. A spatially interactive simulation of climate change, harvesting, wind, and tree species migration and projected changes to forest composition and biomass in northern Wisconsin, USA. Global Change Biology 11:307-321.

Scheller RM, Domingo JB, Sturtevant BR, Williams JS, Rudy A, Gustafson EJ, Mladenoff DJ. 2007. Design, development, and application of LANDIS-II, a spatial landscape simulation model with flexible temporal and spatial resolution. Ecological Modelling 201:409-419.

Scheller RM, Hua D, Bolstad PV, Birdsey RA, Mladenoff DJ. 2011. The effects of forest harvest intensity in combination with wind disturbance on carbon dynamics in Lake States mesic forests. Ecological Modelling 222:144-153.

Scheller RM, Lucash MS, Kretchun A. 2018. LANDIS-II Net Ecosystem Carbon and Nitrogen (NECN) Succession v6.0 Extension User Guide. Raleigh (NC).

Seidl R, Thom D, Kautz M, Martin-Benito D, Peltoniemi M, Vacchiano G, Wild J, Ascoli D, Petr M, Honkaniemi J, Lexer MJ, Trotsiuk V, Mairota P, Svoboda M, Fabrika M, Nagel TA, Reyer CPO. 2017. Forest disturbances under climate change. Nature Climate Change 7:395-402.

Siegert NW, Mccullough DG, Liebhold AM, Telewski FW. 2014. Dendrochronological reconstruction of the epicentre and early spread of emerald ash borer in North America. Diversity and Distributions 20:847-858.

Smith A, Herms DA, Long RP, Gandhi KJK. 2015. Community composition and structure had no effect on forest susceptibility to invasion by the emerald ash borer (Coleoptera: Buprestidae). The Canadian Entomologist 147(3):318-328.
Sturtevant BR, Gustafson EJ, Li W, He HS. 2004. Modeling biological disturbances in LANDIS: A module description and demonstration using spruce budworm. Ecological Modelling 180:153-174.

Sturtevant BR, Gustafson EJ, He HS, Scheller RM, Miranda BR. 2017. LANDIS-II Biological Disturbance Agent v3.0 Extension User Guide.

Taylor KE, Stouffer RJ, Meehl GA. 2012. An overview of CMIP5 and the experiment design. Bulletin of the American Meteorological Society 93:485-498.

Turner MG. 2010. Disturbance and landscape dynamics in a changing world. Ecology 91:2833-2849.

U.S.D.A., Animal and Plant Health Inspection Service. 2003. Emerald ash borer; quarantine and regulations, 68 Fed. Reg. 59082, October 14, 2003, to be codified at 7 C.F.R. pt. 301.

USDA, NRCS. 2020. The PLANTS Database (http://plants.usda.g ov, 29 April 2020). National Plant Data Team, Greensboro, NC 27401-4901 USA.

USFS. 2012. Chequmegon-nicolet national forest land and resource management plan: monitoring and midterm evaluation report 2009-2010. Forest Service, Rhinelander: United States Department of Agriculture.

USGCRP. 2017: Climate Science Special Report: Fourth National Climate Assessment, Volume I. In: Wuebbles DJ, Fahey DW, Hibbard KA, Dokken DJ, Stewart BC, and Maycock TK, Eds. U.S. Global Change Research Program, Washington, DC, USA, 470 pp, doi: https://doi.org/10.7930/J0J964J6.

USGCRP. 2018. Impacts, risks, and adaptation in the United States: Fourth national climate assessment, Volume II: Reportin-brief. In: Reidmiller DR, Avery CW, Easterling DR, Kunkel KE, Lewis KLM, Maycock TK, Stewart BC, Eds. Washington, DC, (USA): U.S. Government Publishing Office, p 186.

Wang GG, Hu H. 2015. The replacement of American chestnut: A range-wide assessment based on data from forest inventory and published studies. In: Holley AG, Connor KF, Haywood JD, Eds. Proceedings of the ${ }^{17 \text { th }}$ biennial southern silvicultural research conference. Asheville, NC, (USA): U.S. Department of Agriculture, Forest Service, Southern Research Station, p 551.

Whyte K, Caldwell C, Schaefer M. 2018. Indigenous lessons about sustainability are not just for 'all humanity'. In: Julie S, Ed. Sustainability: Approaches to Environmental Justice and Social Power. NYU Press, pp 149-79.

Wisconsin Department of Agriculture, Trade and Consumer Protection. (2020). Wisconsin's emerald ash borer information source, https://datcpservices.wisconsin.gov/eab/index.jsp.

Wisconsin Department of Natural Resources. 2015. The ecological landscapes of Wisconsin: An assessment of ecological resources and a guide to planning sustainable management. Wisconsin Department of Natural Resources, PUB-SS-1131 2015, Madison.

Wisconsin Department of Natural Resources. 2018. Wisconsin DNR Forest Health 2018 Annual Report. Madison: Wisconsin Department of Natural Resources.

Wisconsin State Climatology Office. 2016. Historical climate data for northeast Wisconsin. http://www.aos.wisc.edu/ sco/cli m-history/division/4703-climo.html, 13 August 2020. 